\title{
Production Diversity and Constraints in Smallholder Farms in the Bamboutos Mountain
}

\section{Louis Nkembi ${ }^{1}$, Njukeng Jetro Nkengafac ${ }^{2}$, Tankou Christopher Mubeteneh ${ }^{3}$, Deh Nji Herman ${ }^{1}$, Ngulefack Ernest Forghab ${ }^{1}$}

\author{
${ }^{1}$ Environment and Rural Development Foundation (ERuDeF), Civil Society Building, Co-Cathedral Road \\ Molyko Buea, South West Region. \\ ${ }^{2}$ Institute of Agricultural Research for Development (IRAD), Ekona Research Centre, PMB 25 Buea, South \\ West Region. \\ ${ }^{3}$ Department of Crop Sciences, Faculty of Agronomy and Agricultural Science, University of Dschang,
} Cameroon

Corresponding Author: Njukeng Jetro Nkengafac

\begin{abstract}
Smallholder farmer agricultural productivity in developing countries is more often diverse and limited by diverse constraints. For optimal agricultural production and income crops for diversification must be carefully selected and the constraints properly addressed. The objective of this study was to establish a list of the major crops planted in the Bamboutos mountain landscape and the constraints faced by the smallholder farmers. During a survey, 261 household heads responded were randomly selected and the questions administered to them. A majority of the household heads were men and were literate and most of them were younger than 55 years. Crop and livestock production were the main income generating activities of the respondents. Most of the farmers` land sizes were less than $5 \mathrm{a}$ and land ownership was through inheritance, purchase or rent. The small holder farmers in the study area planted a variety of both annual and perennial crops. These crops were sold, consumed or had ornamental/cultural values. The farmers faced a number of problems in animal and crop production with the most cited constraints being lack of inputs, lack of capital, bad roads and climate change. The results of this study suggest that crop diversification should be encouraged within the study area, policy and stakeholder intervention should concentrate on solving the cited constraints for sustainable food production and conservation of biodiversity.
\end{abstract}

Key Words: Crops, Constraints, Diversification, Smallholders

\section{INTRODUCTION}

In Africa, the majority of the undernourished people live in rural areas. Many of them are smallholder farmers and diversifying production on these smallholder farms is widely perceived as a useful approach to food security ${ }^{[1]}$. Production should address not only the quantity of food or calories but high nutrient values such as vitamins, minerals and other micronutrients as well. Smallholder farmers` crop diversity improves farmers` dietary diversity ${ }^{[2]}$. Several recent development initiatives have promoted smallholder diversification through introducing additional crop and livestock species with the intention to improve household nutrition ${ }^{[3]}$. Since farm diversity can help to increase agrobiodiversity, this approach is also welcome from environmental perspectives. In agricultural ecosystems, maintenance of biological diversity is important both for food production and to conserve the ecological foundations necessary to sustain life and rural livelihoods. Agricultural biodiversity includes all the components of biological diversity of relevance to food and agriculture together with the components of 
biological diversity that constitute the agroecosystem: the variety and variability of animals, plants and micro-organisms, at the genetic, species and ecosystem levels, that sustain the functions, structure and processes of the agroecosystem ${ }^{[4]}$. This diversity has been shaped by farmers and communities and remains a key element of the livelihood strategies of poor, small-scale farmers throughout the world. Production diversity is considered a critical measure of the agricultural health of the world. Not only does increased production diversity contribute to nutrient production and consumption, but it acts as a safeguard against food shortages due to pests and diseases by spreading the risk ${ }^{[5]}$. As a result, production diversity is often highlighted in global discussions related to food security. Individuals who are food secure and have the ability to acquire adequate food for a healthy and active life, are more likely to be able to contribute significantly to the economy than their undernourished counterparts ${ }^{[6]}$.

Crop diversification is the introduction or development of additional crops to the existing farming system ${ }^{[6]}$. Horizontal crop diversification is the addition of more crops to the existing cropping system ${ }^{[7]}$. Crop substitution and adjustment which are related to the primary concept of crops diversification are ways of optimizing profit and managing land ${ }^{[8]}$. Diversification at farm level involves growing more than one crop in order to achieve self-sufficiency which is different from diversification at national level. At the national level, crop diversification will require additional resources and management of a specific or group of drops sold freshly or value added to increase profits ${ }^{[9]}$.

Smallholder farming continues to play a key role in agriculture. However, they face a lot of constraints ranging from climate variability, lack of appropriate infrastructure, poor farming skills, soil degradation ${ }^{[10]}$. Drought, pests and diseases often worsen the situation in some cases resulting in complete crop failure there by perpetuating poverty in rural communities. Soils in most smallholder's farms are highly degraded due to poor farming practices that lead to nutrient depletion without adequate replacement with fertilizers or manures. This often leads to low yields and low farm income.

Mount Bamboutos Landscape is a mountainous area which provides favorable growth conditions of several temperate crops already being cultivated in the area such as potato, cabbage, carrot, leeks etc. However, many more temperate crops could be added such as wheat, pear, etc. Production diversity would open the way for different crop rotation options which would help to curb disease and pest problems. Besides its biodiversity uniqueness, this mountain remains the only ecosystem in the country cutting across three administrative Regions which are West, South West and North West, and involving over 20 villages with a population of 20,000 to 30,000 people. Most of these people depend on the mountain and its biodiversity content for their livelihood; they practice slash-andburn and clear the forest to make way for farmland leading to high rates of deforestation, destruction of water catchments, disappearance of fuel wood and loss in soil fertility ${ }^{[11]}$. The Environment and Rural Development Foundation (ERuDeF)- a Cameroonian nongovernmental organization and other stake holders are preparing a 15 year management plant for the Bamaboutos Mountain which will help to restore its biodiversity. This study aims to understand the current production diversity and constraints of farmers in the Bamboutos Mountain. The results will be used by the intervening organisations as they develop and implement the Bamboutos management plan.

\section{MATERIALS AND METHODS The study Area}

This study was carried out in the Bamboutos Mountain landscape of the 
Western High Plateau of Cameroon. It lies between latitude $5^{\circ} 32^{\prime}$ and $5^{\circ} 51^{\prime}$ North of the equator and longitude, 956' and 1009' east of the Greenwich Meridian. The mean maximum temperature is between $20-22^{\circ} \mathrm{C}$; mean minimum $13-14^{\circ} \mathrm{C}$. November has the lowest mean minimum temperature and December the highest mean maximum. Rainfall varies from $1780-2290 \mathrm{~mm}$ per year with. July and September being the months with the highest rainfall. The monthly average humidity exceeds $80 \%$ in July and August while January and February have the lowest relative humidity (average $45-52$ $\%)$. Three main categories of soils can be found in the Bamboutos mountain: soils with andic characteristics, ferrallitic soils and imperfectly developed soils. This offers the advantage that a variety of crops and animals can be produced in the area.

\section{Data collection and Statistical analysis}

Eleven villages were randomly selected and questionnaires administered to the farmers in these villages. On a whole, a total of 261 questionnaires were administered. Data gathered included; respondents demographic attributes, land tenure, farm size, agricultural activities, types of crops and trees planted, animal rearing activities, fish farming activities and constraints faced during agricultural production.

Data obtained from the study were analysed, using descriptive statistics (frequencies and percentages). Results were presented in tables and figures. Production diversity on farm was a simple count of different species produced ${ }^{[12]}$.

\section{RESULTS AND DISCUSSION Demographic attributes of respondents in the study area}

The results as presented in Table 1 show that most $(69 \%)$ of the household heads were men. A majority $(73 \%)$ of the sampled population were younger than 55 years, an indication of a very active farming population. There were very few illiterates (16\%) with $49 \%$ respondent haven resided in the village for more than 30 years. Duration in a village is an indication of the stability of the respondent. Farmers who stay longer in an area can acquire and own agricultural and livestock assets. The minimum household size was 1 , the average 8 and the maximum household size was 45 persons. The large household size confirms the fact that some respondents were polygamists, thus having many wives and children. The mud brick house type was the most common in the study area. House type is sometimes used to characterized respondents into wealthy and unwealthy families. Cement block house owners are considered to be wealthier than mud bricks house owners.

Table 1. Socio economic characteristics distribution

\begin{tabular}{|c|c|c|c|}
\hline $\begin{array}{l}\text { Socio economic } \\
\text { variable }\end{array}$ & variable & $\begin{array}{l}\text { Freque } \\
\text { ncy }\end{array}$ & $\begin{array}{l}\text { Percent } \\
\text { age }\end{array}$ \\
\hline \multirow[t]{2}{*}{ Sex } & Male & 180 & 69 \\
\hline & Female & 81 & 31 \\
\hline \multirow[t]{4}{*}{ age } & $16-35$ & 74 & 28.4 \\
\hline & $36-55$ & 117 & 44.8 \\
\hline & $56-75$ & 66 & 25.3 \\
\hline & $>75$ & 4 & 1.5 \\
\hline \multirow[t]{6}{*}{ education level } & Illiterate & 42 & 16.1 \\
\hline & primary school & 127 & 48.7 \\
\hline & secondary school & 61 & 23.4 \\
\hline & high school & 26 & 10.0 \\
\hline & university & 3 & 1.2 \\
\hline & Degree holder & 2 & 0.8 \\
\hline \multirow{5}{*}{$\begin{array}{l}\begin{array}{l}\text { duration } \\
\text { village }\end{array} \\
\end{array}$} & $1-15$ years & 51 & 19.5 \\
\hline & $16-30$ & 83 & 31.8 \\
\hline & $31-45$ & 55 & 21.1 \\
\hline & $46-65$ & 59 & 22.6 \\
\hline & $>65$ & 13 & 5.0 \\
\hline \multirow[t]{4}{*}{ House hold size } & $1-5$ people & 93 & 35.6 \\
\hline & $6-9$ & 98 & 37.6 \\
\hline & $10-13$ & 42 & 16.1 \\
\hline & $14 \&$ above & 28 & 10.7 \\
\hline \multirow[t]{4}{*}{ Housing type } & Mud brick & 209 & 80.1 \\
\hline & Cement blocks & 27 & 10.3 \\
\hline & $\begin{array}{l}\text { Mud bricks }+ \\
\text { cement block }\end{array}$ & 12 & 4.6 \\
\hline & Others & 13 & 5.0 \\
\hline
\end{tabular}

Respondents farm sizes and tenure system in the study area

Table 2. Farm sizes and land tenure
\begin{tabular}{|l|l|l|l|}
\hline Variable & Variable Details & Frequency & Percentage \\
\hline Farm size & $0.1-1.9$ ha & 39 & 14.9 \\
\hline & $2-3.9$ ha & 29 & 11.1 \\
\hline & $4-5$ ha & 13 & 5.0 \\
\hline & $>5$ ha & 10 & 3.8 \\
\hline & Not known & 170 & 65.1 \\
\hline & Inherited & 126 & 48.3 \\
\hline Land tenure & Purchased & 64 & 24.5 \\
\hline & Rented & 62 & 23.8 \\
\hline & others & 10 & 3.8 \\
\hline
\end{tabular}


Land possession for agricultural practice is an important asset for providing food and non-food needs of the rural households ${ }^{[13]}$ and access to land is a key factor in reducing rural poverty and ensuring food security ${ }^{[14]}$. Thus land ownership is very important for farmers. The results of this study show that a farmer can own land through; inheritance, purchase, rents or other means like share cropping. In this study most farmers acquired their land through inheritance (Table 2). Inherited land is handed from one generation to another. Farm sizes were generally small, less than 5ha. This is a typical characteristic of smallholder farmers. The land size is most often equal to the resources of the farmer. It is important to note here that most respondents $(65 \%)$ were not able to know their farm sizes. This is a challenge that needs to be addressed especially when inputs are to be distributed to the farmers as a strategy to improved production. The local agriculture extension service will be of much help to the farmers in this like.

\section{Respondent's major agricultural outputs and livestock reared in the study area}

The main income generating activities carried out by farmers in the study area were crop production and animal rearing. Table 3 shows that most respondents $(68 \%)$ were involved in livestock production and fish production was negligible in the study area. Pig and chicken were the most reared livestock. The number of animals/birds ranged between 1 and 50. This shows that the animal farms were generally small. Livestock contributes to food security status of households in different ways such as by providing cash income, nutrition, manure etc ${ }^{[1]}$. Studies have shown that households that own livestock are more likely to diversify their diet than those that do not own livestock ${ }^{[15]}$

Table 3. Major livestock reared

\begin{tabular}{|l|l|l|l|l|l|l|l|}
\hline Activity/ & livestock & Fishing & Cattle & Pig & Goat & Sheep & Chicken \\
\hline Yes & 178 & 9 & 20 & 177 & 96 & 31 & 179 \\
\hline No & 78 & 242 & 237 & 81 & 162 & 226 & 79 \\
\hline number & & & $1-50$ & $1-30$ & $1-50$ & $1-50$ & $1-50$ \\
\hline
\end{tabular}

\section{Respondents` major perennial crops}

Perennial crops cultivated in the study area had four major uses; for consumption, sale, medicinal and cultural. The most cultivated perennial crops were Avocado and Banana (Table 4). The climatic conditions of the study area are very suitable for these two crops; in fact the study area is one of the best regions of the country for the cultivation of Avocado. Cocoa which is one of the least cultivated perennial crops is not a traditional crop of the area, it is just being introduced. This accounts for the fact that it is being planted in very few farms.

Table 4. Perennial Crops cultivated

\begin{tabular}{|l|l|l|l|}
\hline Crop (common name) & Scientific name & Number of farms growing it & Frequency (number of farms) \\
\hline Banana & Musa spp & 89 & 34.0 \\
\hline Avocado & Persea americana & 105 & 40.2 \\
\hline Kola nuts & Cola spp & 51 & 19.5 \\
\hline Mangoes & Mangifera indica & 11 & 4.2 \\
\hline Coffee & Coffea arabica & 11 & 4.2 \\
\hline Raphia & Raphia vinifera & 22 & 8.4 \\
\hline Citruses & Citrus spp & 12 & 4.6 \\
\hline Guava & Psidium gaujava L. & 18 & 6.9 \\
\hline Safou & Dacryodes edulis & 6 & 2.3 \\
\hline Eucalyptus & Eucalyptus globulus & 13 & 5.0 \\
\hline Sugar cane & Saccharum spp & 4 & 1.5 \\
\hline Paw paw & Carica papaya & 4 & 1.5 \\
\hline Pineapple & Ananas comosus & 4 & 1.5 \\
\hline Cocoa & Theobroma cacao L. & 2 & 0.8 \\
\hline
\end{tabular}




\section{Respondents' major annual crops}

Annual crops are short cycle crops that are cultivated for consumption and sale. The most cultivated crops are potato, beans and maize (Table 4). These are the stable crops of the study area ${ }^{[16]}$. Vegetables and spices are also cultivated for home consumption and sale.

Table 4. Major Annual crops

\begin{tabular}{|l|l|l|l|}
\hline Crop (common name) & Scientific name & Frequency (number of farms & Percentage \\
\hline Potato & Solanum tuberosum & 184 & 70.5 \\
\hline Cabbage & Brassica oleracea & 45 & 17.2 \\
\hline Carrot & Daucus carota & 77 & 29.5 \\
\hline Maize & Zea mays & 78 & 29.9 \\
\hline Beans & Phaseolus vulgaris & 85 & 32.6 \\
\hline Leeks & Allium porrum & 69 & 26.4 \\
\hline Yams & Dioscoria esculenta & 10 & 3.8 \\
\hline Persley & Petroselinum crispum (Mill) & 11 & 4.2 \\
\hline Celery & Apium graveolens & 19 & 7.3 \\
\hline Cocoyam & Xanthosoma sagittifolium & 44 & 16.9 \\
\hline Onion & Allium cepa L. & 10 & 3.8 \\
\hline
\end{tabular}

Pattern of crop diversity practiced by the respondents

Table 5 presents the extent of crop diversification, where the study used descriptive statistics to describe the extent of crop diversification among the farming households.

Table 5. Crop diversity pattern

\begin{tabular}{|l|l|l|}
\hline No of crops cultivated & Frequency & Percentage \\
\hline $1-3$ & 166 & 63.6 \\
\hline $4-6$ & 66 & 25.3 \\
\hline $7-9$ & 29 & 11.1 \\
\hline
\end{tabular}

From table 5 it is shown that $63.6 \%$ of households within the study area cultivated 1 to 3 different crops, 4 to 6 crops were cultivated by $25.3 \%$ of the respondents and $11.1 \%$ of respondents cultivated greater than 7 crops. The minimum number of crops cultivated by respondents was 1 and maximum was 9. Averagely, 4 different crops were planted by respondents. Crop diversification can be used as a tool to increase farm income, improve nutrition, generate employment, alleviate poverty, conserve soil and water resources and it is well known as an important strategy to overcome many of the emergencies faced by developing countries ${ }^{[17,18]}$

\section{Smallholder farmers' production Constraints}

The results of this study show that most of the households depend on crop and animal production for their livelihoods.
There were several production problems raised by the respondents. If these problems are not properly addressed, the level of destruction of the biodiversity of the study area may not be checked. Major problems of crop production in the study area (Figure 1) were:

High cost of inputs (planting seeds, fertilisers and pesticides) were among the major problems faced by farmers in the study site (Figure 1). About 26\% of the interviewed farmers cited high cost of inputs as a constraint. There is need for more seed producers to be trained and if possible provided with capital so that seeds can be available and affordable to local farmers. Commercial fertilisers are generally expensive, rendering most of the smallholder farmers in the area unable to purchase adequate quantities. On the other hand, organic fertilisers such as cattle manure, pig manure were often inadequate and of poor quality. The fertiliser shortage problem was compounded by the inherent poor soil fertility status of the land cultivated by these farmers as poor soils and soil erosion were among the challenges cited by them (Figure1).

Problems of lack of pesticides to control insect pests and diseases were a serious problem as pests and diseases was one of the greatest challenges faced by the farmers. Pesticides are essential for high yield and good quality vegetable production [10]. Problems of limited inputs and pests 
and disease could account for the overall farmers.

low yields cited as a constraint for these

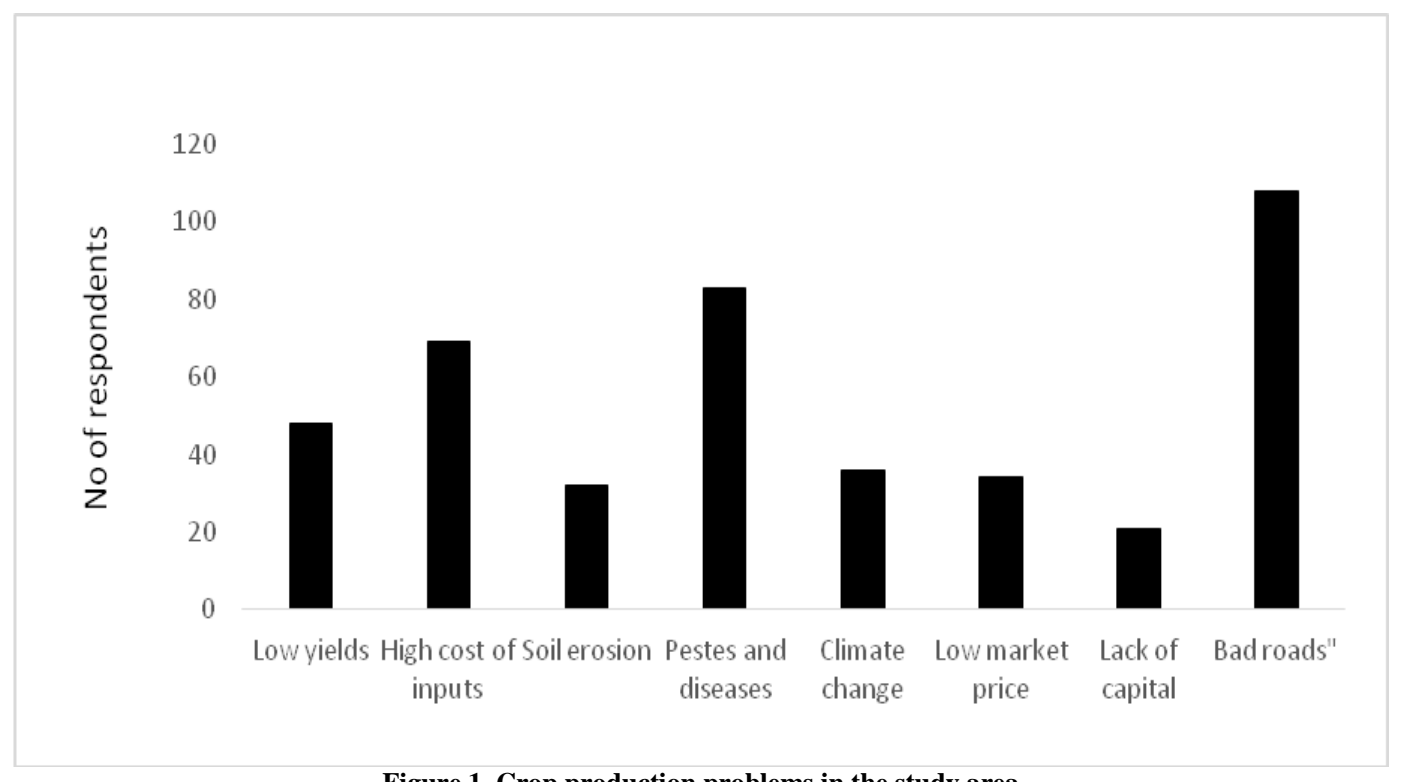

Figure 1. Crop production problems in the study area

Bad roads were the most cited $(40 \%)$ constraint. Bad roads could account for the high post harvest loss and transportation cost. Harvested crops will not reach the market on time and with bad roads, farmers are asked to pay more money for transportation.

Climate change cited as a constraint by $14 \%$ of the respondents, has been associated to irregular rainfall, which can lead to crop failure especially in the study area where farmers have little or no irrigation facilities. Although a few persons mentioned animal ravaging as a constraint, it is important to look for a means to reduce it especially if the flora and fauna of this ecosystem is to be restored. When farmers' crops are destroyed by animals, there will be a tendency for the farmers to kill the animals. More so farmer grazer conflict must be avoided for peaceful coexistence. Lack of capital and low market prices were also cited as constraints. Access to markets is an essential requirement for the poor in rural areas to enjoy the benefits of agricultural growth. Limited access to agricultural markets by smallholder farmers in rural areas represents one of the most important challenges confronting policy makers in developing countries ${ }^{[19]}$.
Formation of cooperatives could address the problems of low market prices and lack of capital. Farmers can sell their produce through cooperatives where the price will be better and they can borrow capital as members of the cooperatives.

If these problems are not addressed fully or partially, they will lead to more serious production and post-harvest losses, thereby impacting negatively on household incomes and food supplies. There is need for extension agencies and other stakeholders such as NGOs to assist farmers to tackle the above-mentioned problems.

The greatest problem faced by smallholder farmers in animal production is pests and diseases (cited by $30 \%$ of the respondents) (Figure 2). This is further aggravated by poor veterinary services. Similar constraints were encountered by rural farmers in Adamawa State, Nigeria ${ }^{[20]}$ . Pests and diseases have been found as key threats that impact agriculture in developing countries $^{[21]}$.

If training institutions are built and farmers trained on long or short term, it will go a long way to solve the problems cited by farmers. Farmers will be trained on local production of feed which will solve the problem of lack of feed. Adequate training 
will enable farmers to handle uncomplicated veterinary problems faced by their animals and birds.

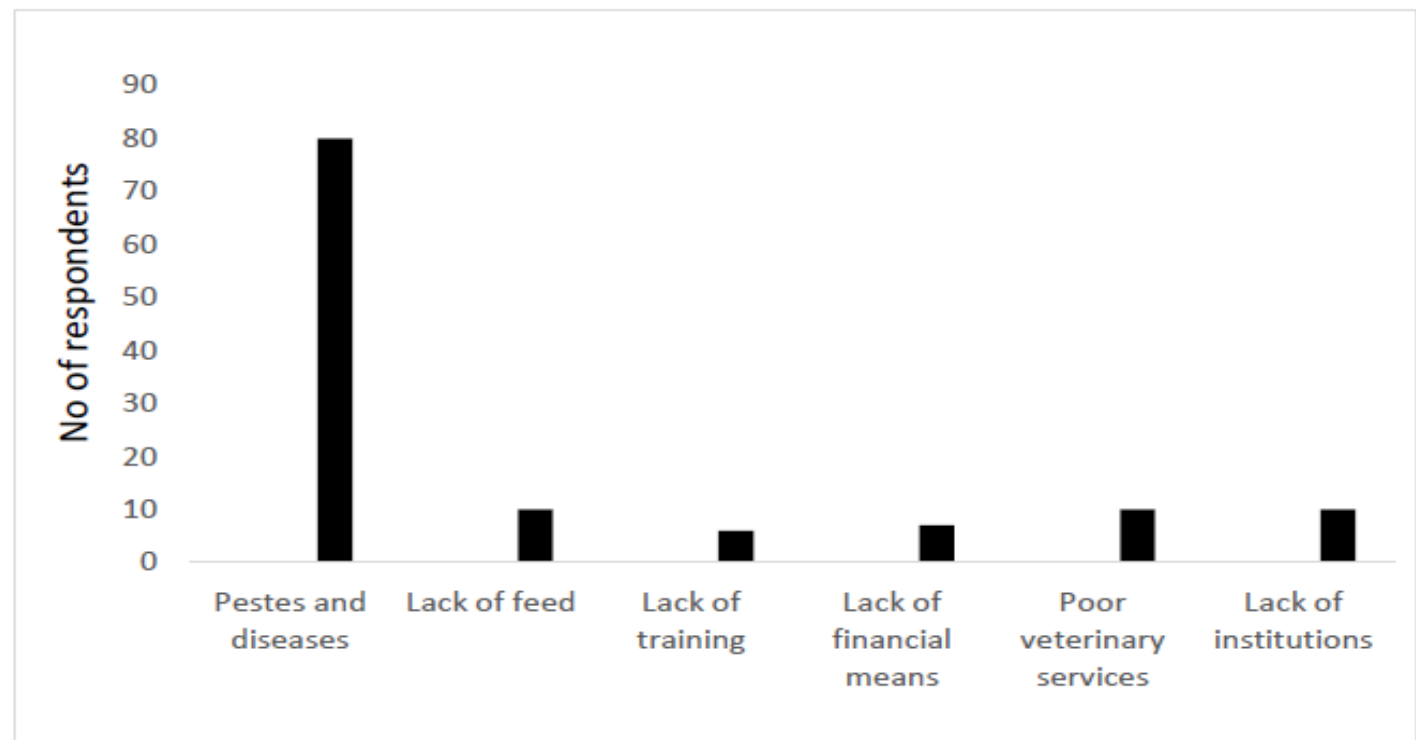

Figure 2. Animal production problems in the study area

\section{CONCLUSION}

This study documented production diversity in smallholder farms around the Bamaboutos Mountain. The smallholder farmers plant both annual and perennial crops that are either consumed, sold, used in medicine and/or as ornamentals. The outcome of the study suggests that crop diversification should be encouraged in the study area. The constraints face by these farmers in crop and animal production are many notably among them are; lack of inputs, pest and diseases, lack of technical know-how, bad roads and lack of capital. These identified constraints provide entry points for policy and stakeholder intervention, for sustainable livelihood development and a better management of the Mount Bamboutos ecosystem. Policy which improves rural farm household income should be put in place and activities that can help increase farm household offfarm income should be encouraged.

\section{ACKNOWLEDGEMENTS}

The financial support from the Darwin Initiative and TreeSisters for the conduct of this study is greatly acknowledged. We thank the International Tree Foundation (ITF) for the technical support offered during the execution of this project. We acknowledge the collaboration of the smallholder farmers in the Bamboutos Mountain.

\section{Conflict of Interest: None}

Source of Funding: Darwin Initiative and TreeSisters

\section{REFERENCES}

1. Adjimoti G O, Kwadzo G T. Crop diversification and household food security status: evidence from rural Benin. Agriculture \& Food security. 2018; 7:82.

2. Gbenga O, Opaluwa HI, Adedeji SO, Abdulrahman S. Effect of crop diversity on rural farming household's dietary diversity. Journal of Asian Rural Studies. 2020; 4(2): 218-229.

3. Toledo A, Burlingame B. Biodiversity and Nutrition: A Common Path towards Global Food Security and Sustainable Development. Journal of Food Composition and Analysis. 2006; 19: 477-483

4. Van der Waals JE Korsten L, Slippers B. Genetic Diversity among Alternaria solani Isolates from Potatoes in South 
Africa. Plant Disease. 2004; 88: 959964.

http://dx.doi.org/10.1094/PDIS.200.

5. van Niekerk C, Hettie S, Hall N, Beulah $\mathrm{P}$. The role of Biodiversity in Food Security and Nutrition: A potato Cultivar case study. Food and Nutrition Sciences. 2016; 7: 371-382.

6. Moretti C L, Mattos L M, Calbo AG, Sargent SA. Climate Changes and Potential Impacts on Postharvest Quality of Fruit and Vegetable Crops: A Review. Food Research International. 2010: $\quad$ 43: 1824-1832. http://dx.doi.org/10.1016/j.foodres.2009. 10.01 .

7. FAO, IFAD, \& WFP. The state of Food insecurity in the world. Meeting the 2015 international hunger targets: taking stock of uneven progress. Rome; 2015. http://www.fao/3/a-i4646e.pdf.

8. MINADER, Stratègie de Développement du Secteur Rural (SDSR), Synthèse du Volet Agriculture et Développement Rural. In Stratègie de Développement du Secteur Rural (SDSR), synthèse du Volet Agriculture et Dévelopment Rural, Yaoundé, Cameroun, MINADER, 57, 2006.

9. Yengoh GT, Ardö J. Crop yield gaps in Cameroon. AMBIO. 2014; 43: 175 190. DOI 10.1007/s13280-013-0428-05.

10. Makuvaro V, Walker S, Munodawafa A, Chagonda I, Masere R, Murewi C, Mubaya C. Constraints to crop production and adaptation strategies of smallholder farmers in semi -arid central and Western Zimbabwe. African Crop Science Journal. 2017;25(2): 221235

11. Tankou, C.M., de Snoo, G.R., de Iongh, H.H. and Persoon G. Soil Quality Assessment of Cropping Systems in the Western Highlands of Cameroon. International Journal of Agricultural Research. 2013; 8(1):1-16.

12. Sibahatu KT, Krishna VV, Qaim M. Production diversity and dietary diversity in smallholder farm households. Proceedings of the National
Academy of Sciences, USA. 2015; 112:10657-10662.

13. Mawunu M, Eduardo A, Balomba P, Asaph M A, Gedeom B, Koto-te-Nyiwa N. Food security and Livelihood of Rural Households of Songololo Territory in Kongo Central Province, Democratic Republic of Congo. International Journal of Health Economics and Policy. 2017; 2(3):97103.

14. Jayne TS, Zulu B, Mather D, Mghenyi E, Chirwa E, Tschirley D. 2005). Maize marketing and Trade Policy in a Propoor Agricultural Growth Strategy: Insights from Household surveys in Eastern and Southern Africa. A paper prepared for conference "Towards improved maize marketing and Trade policies in the Southern Africa Region" Sponsored by FANRPAN/ Rocker Feller Foundation, Pretoria, South Africa, June 21-22.2005.

15. Geremew M J, Akalu D S, Beneberu A W. Determinants of household dietary diversity in Yayu Biosphere Reserve, Southwest Ethiopia. Ethiopian Journal of Science and Technology. 2019; 12(1): 45-68.

16. Tabi FO, Bitondo D, Yinda GS, Kengmegne SSA and Ngoucheme $\mathrm{M}$. Effect of long- term integrated soil fertility management by local farmers on nutrient status of a Typic Dystrandept under potato-based cropping system. International Research Journal of Agricultural Science and Soil Science. 2013; 3(4): 134-140.

17. Joshi PK, Gulati A, Birthal SP, Laxmi T. Agricultural diversification in South Asia: patterns, determinants and policy Implications. Economic and Political Weekly. 2004; 39(24): 2257-2467.

18. Frison EA, Cherfas J, Hodgkin T. Agricultural biodiversity is essential for a sustainable improvement in food and nutrition security. Sustainability. 2011; 3:238-253.

19. Baloyi J K. An analysis of constraints facing smallholder farmers in the 
Agribusiness value chain: A case of farmers in the Limpopo Province. Master thesis submitted to the Department of Agricultural Economics, Extension and Rural Development, Faculty of Natural and Agricultural Sciences, University of Pretoria, Pretoria, South Africa. 2010; Pp119.

20. Haaddabi AS, Ndehfru NJ, Aliyu A. Analysis of food security status among rural farming households in Mubi North local government area of Adamawa state, Nigeria. International Journal of Research - Granthaalayah. 2019;7(7): 226-246.
21. Miyinzi CM, Shikuku KM, Atibo C, Mwongera C. Survey-based data on food security, nutrition and agricultural production shocks among rural farming households in northern Uganda. Data in brief. 2019:23, 103818.

How to cite this article: Louis Nkembi, Njukeng Jetro Nkengafac, Tankou Christopher Mubeteneh et.al. Production diversity and constraints in smallholder farms in the Bamboutos Mountain. International Journal of Research and Review. 2021; 8(4): 269-277. DOI: https://doi.org/10.52403/ijrr.20210434 